\title{
Pharmaceutical wastewater treatment using free and immobilized Cyanobacteria
}

\author{
Shabana, E. F., Senousy, H. H. and Khourshid, E. B. \\ Botany and Microbiology Department, Faculty of Science, Cairo University, Egypt.
}

\begin{abstract}
:
An attempt has been made to study the feasibility of pharmaceutical wastewaters (laboratories waste (WI) and production waste (WII)) treatment using free and immobilized cyanobacterium Phormidium fragile. After preliminary test with different concentrations, WI showed high toxicity, only $0.5 \%$ conc. was effective while WII was used at high conc. of $40 \%$ after 10 days incubation (from growth curve experiment) in optimum growth conditions. Role of Phormidium cells in bioremediation of pharmaceutical wastewaters was effective whereas maximum percentage removal in tested parameters were $51.56 \%$ and $58.89 \%$ for ammonia, $66.67 \%$ and $61.23 \%$ for phosphorus, $51.74 \%$ and $54.55 \%$ for COD and $37.05 \%$ and $59.85 \%$ for BOD in WI and WII respectively with respect to treatments without microalgae. N-starvation for 36 hours prior to cultivation caused increase in percentage removal of ammonia, phosphorus and COD with increase in algal dose than unstarved cells, 100\%, 100\% and $72.56 \%$ for WI and $87.28 \%, 100 \%$ and $71.98 \%$ for WII, respectively with $40 \mathrm{ml}$ algal dose. It was found that 2500 lux and $25{ }^{\circ} \mathrm{C}$ were the best for nutrients removal. Chlorophyll a, dry weight, protein and total carbohydrate contents were also estimated. During this study, $\mathrm{pH}$ levels increased and remained in the range 7.3 to 9.1. Significant removal of ammonia, phosphorus and COD were observed in algal alginate beads treatments than blank beads. Starvation before immobilization recorded the highest removal percentage when compared to unstarved beads or free cells in both wastes types and their mixture (1:1). When starved and unstarved Phormidium beads were incubated in WI, WII and a mixture of both in a semi-continuous system for five consecutive cycles (10 days each), there was increase in nutrients percentage removal up to the third cycle. Microalga in the beads survived long enough which gives a promise to upgrading immobilization technique for wastewater treatment with low cost.
\end{abstract}

Keywords: Cyanobacteria, Phormidium, Pharmaceutical wastewater treatment, starvation, immobilization, alginate beads. 


\section{Introduction}

The pharmaceutical industry is one of the most important for modern civilization. Increasing number of pharmaceutical industries leads to hazardous impact on water quality and thus affects the surrounding environment and human health. Thus, the pharmaceutical industry has become one of the major causes of concern. The day by day increased level of water pollution highlights the need for time to time assessment/characterization of pharmaceutical industrial wastewater (Rana et al., 2014). Many pharmaceuticals and personal care products (PPCPs) have been designed to stay active for long periods of time to fulfill their therapeutic function; thus, they can persist in the environment, remaining active and affecting aquatic life (Ricart et al., 2010; Kvarnryd et al., 2011).

In fact, the pharmaceutical industry is characterized by a diversity of products, processes, plant sizes, as well as wastewater quantity and quality. Hence, it is almost impossible to describe a "typical" pharmaceutical effluent because of such diversity, wastewater treatment and disposal problems have also increased as a result (Dixit and Parmar, 2013). Though the volume of untreated or incompletely treated pharmaceutical industry wastewater is small, it contains a high level of pollutants because of the presence of nonbiodegradable organic matter and other pollutants (Vuppala et al., 2012; Ramola and Singh, 2013). Untreated pharmaceutical wastewater discharge into the natural environment causes health hazards to existing flora and fauna and therefore, treatment of the effluents is necessary to bring down the concentration of toxic substances to desired limits, before they are finally discharged into the natural systems (UNESCO, 2005). In order to design an appropriate treatment system the characteristics of the generated wastewater need to be followed and analyzed. Nowadays, pharmaceutical companies employ a variety of treatment methods, which includes primary: chemical and physicochemical, secondary: biological process and tertiary: advanced oxidation processes which utilize costly chemicals and treatment units, which are difficult to manage at the industrial unit level (Amin et al., 2013; Vanerkar et al., 2013). 
Phycoremediation is a novel, low cost and an effective technique that uses algae to clean up wastewater offering very simple and economical method as compared to the other conventional treatments (Elumalai et al., 2013). Also microalgae have an effective role in the uptake of the pollutants to use inorganic nitrogen and phosphorus for their growth as well as their ability to produce valuable biomass that can be used in different industrial applications (Tam and Wong, 1995). Successful treatment of wastewater with microalgae requires understanding of the factors that affect growth such as physical, chemical and biological factors (Larsdotter, 2006). The major problem in utilization of microalgae in any industrial or wastewater treatment is harvesting of the biomass. This is solved by the strategy of immobilization. This precludes the use of supporting material obtained either naturally including agar, alginate and carrageenan or synthetics such as polyacrylamide and polyurethane (Vijayakumar, 2012). The aim of the present study is treatment of the pharmaceutical wastewaters with free and immobilized cyanobacteria under different conditions in a trial for bioremediation and also testing the growth and synthesis of some metabolites of the used cyanobacterium were undertaken for further applications.

\section{Materials and Methods}

\section{Organism and growth conditions:}

The filamentous fresh water cyanobacterium Phormidium fragile was selected for the current study, it was kindly supplied from the culture collection of Botany and Microbiology Department, Faculty of Science, Cairo University, Egypt. It was routinely grown in BG 11 medium (Rippka et al., 1979) at continuous illumination with light intensity of $48.75 \mu \mathrm{Em}^{-2} \mathrm{~s}^{-1}$ (2500 lux) at $25 \pm 2$ ${ }^{\circ} \mathrm{C}$. The start inoculum was adjusted to be approximately $1.297 \mu \mathrm{g} \mathrm{ml}{ }^{-1}$ chlorophyll a. Optimum growth period was found to be 10 days (cells in the exponential phase) as determined from growth curve experiment. 


\section{Pharmaceutical wastewater:}

The pharmaceutical wastewaters used in this study were obtained from a pharmaceutical company in $6^{\text {th }}$ of October city, $1^{\text {st }}$ industrial zone on February 2017 in one liter capacity bottles. They are two types: Wastewater I (Laboratories waste WI), it was collected from chemical laboratories safety cans, it includes inorganic acids and bases, organic solvents, metals, unused chemicals and chemical reactions products and Wastewater II (Production Waste WII), it was collected by mixing equal volumes from the washing rinse of different production departments, it include parenteral, solids (Tablets and Capsules), semisolids, (cream, ointment, gel and suppository), syrups, antibiotics, instant and powders. Both waste types were separately collected and analyzed pre and post experiments within few hours from collection according to standard procedures of APHA (2012). Wastes were immediately preserved in refrigerator at $4{ }^{\circ} \mathrm{C}$. Thereafter the primary treated wastes were kept in a deep freezer at $-20^{\circ} \mathrm{C}$ until used (Fedorova et al., 2014).

\section{Methods of experimentation:}

After preliminary experiments serial dilutions of wastewaters were prepared by mixing primary treated wastewater and distilled water to obtain concentrations of $0.5 \%, 1 \%, 2 \%, 3 \%$ and $4 \%(\mathrm{~V} / \mathrm{V})$ for wastewater I and $10 \%$, $20 \%, 40 \%, 60 \%$ and $80 \%$ (V/V) for wastewater II. Triplicate flasks from all treatments each containing $300 \mathrm{ml}$ primary treated wastes in addition to control (BG11) were inoculated with $20 \mathrm{ml}$ of Phormidium fragile culture. After 10 days incubation in optimum conditions cyanobacterial cells were harvested and growth parameters were measured in terms of chlorophyll a (Sartory and Grobbelaar, 1984), dry weight (APHA, 2012), total carbohydrates (Dubois $\boldsymbol{e t}$ al., 1956) and protein (Lowry et al., 1951), in addition to BOD, COD (APHA, 2012), ammonia (Chaney and Marbach, 1962) and phosphorus using Fiske-Subbarow method (Clark and Switzer, 1977) of treated wastewaters were also analyzed. Next, the most efficient conc. selected from each waste but with no cyanobacterial inocula was prepared and used as negative control. The chosen wastes concentrations were used for the next experiment in which a series of cyanobacterial suspension inocula $(5,10,20,30,40 \mathrm{ml})$ were inoculated in conical flasks containing $300 \mathrm{ml}$ waste each. A parallel group of flasks in which Phormidium fragile was 
previously nitrogen starved for 36 hours before inoculation. All treatments of starved and unstarved microalgal cells were incubated for 10 days after which growth parameters and wastewaters were analyzed. Two ecological factors, light intensity $(2500,8000$ and 12000 lux $)$ and temperature $\left(15 \pm 2{ }^{\circ} \mathrm{C}, 25 \pm 2{ }^{\circ} \mathrm{C}\right.$ and $40 \pm 2$ $\left.{ }^{\circ} \mathrm{C}\right)$ were tested to study their role in pharmaceutical wastewater bioremediation by Phormidium fragile.

For the formation of the immobilized cyanobacterial beads, the same inoculum of Phormidium was washed twice with double distilled water and initial chlorophyll a was determined. The required quantity was added as a suspension to the sodium alginate solution $(5 \% \mathrm{~W} / \mathrm{V})$ in distilled water after sterilization and cooling under aseptic conditions, alginate beads were formed by using a peristaltic pump to obtain (bead average diameter $\approx 0.5 \mathrm{~cm}$ ), by drop wise into calcium chloride $\mathrm{CaCl}_{2} 0.2 \mathrm{M}$ solution using magnetic stirrer during the preparation for two hours to maintain the shape stability (Rai and Mallick, 1992). The same steps were repeated on the nitrogen starved alga and empty alginate beads (without microalga). Fifty beads were added in each flask which containing 200 $\mathrm{ml}$ waste. The same steps were repeated on a mixture (1:1) from waste I $(0.5 \%)$ and waste II (40\%) freshly prepared for immobilized Phormidium cells either starved or unstarved, in addition to blank beads. At the end of incubation period microalgal beads were separated from the wastewater by filtration and the wastes were analyzed for ammonia, phosphorus and COD. Phormidium alginate beads used in the previous experiment were used in five consecutive cycles (10 days each) with fresh waste which was analyzed after each cycle in a semi-continuous mode in a trial to test the long term effect of microalgal beads in wastewater treatment.

\section{Statistical analysis:}

The means and standard deviation values of the triplicates for each treatment were calculated. The data were analyzed statistically on the basis of analysis of variance (ANOVA). All statistical analyses were carried out using SPSS program (IBM, version 23). 


\section{Results and Discussion}

Some raw and treated pharmaceutical wastewaters (Laboratories WI and Production WII) characteristics were analyzed before the beginning of the experiments (Table 1). $\mathrm{pH}$ value of WI was 10.3 and became 7 after neutralization. Both wastes were filtered, total, suspended and dissolved solids were much lower in treated (filtered) wastes, all were higher in WII than in WI. Shabana (1994) mentioned that filtration helps in removal of solid particles which leads to decrease of some pollutants by adsorption on its surface. Decrease in ammonia, phosphorus, anions and cations, was observed in treated wastes. An observed decrease in COD and BOD by filtration with higher values in WII than WI, yet both values are still exceeding the official limits for wastewater disposal. At high $\mathrm{pH}$ (8.5 or above) especially in presence of calcium ion, some of the phosphorus will be precipitated in the form of orthophosphate which is the case for WII in this study (Jimenez- Perez et al., 2004).

The effect of different concentrations of pharmaceutical wastewaters WI and WII after preliminary experiment on the synthesis of pigment and metabolites in terms of chlorophyll a, dry weight, protein and total carbohydrates is shown in (Table 2). Chlorophyll a content for Phormidium fragile culture decreased significantly $(\mathrm{P}<0.05)$ with increase in waste I concentration to reach minimum value $\left(1316.00 \mu \mathrm{gL}^{-1}\right)$ at $4 \%$ conc. The highest chlorophyll a value was recorded at $0.5 \%$ conc. $\left(2026.33 \mu \mathrm{gL}^{-1}\right)$.

In waste II treatments there was a significant increase in chlorophyll a content up to $40 \%$ conc. $\left(2203.67 \mu \mathrm{gL}^{-1}\right)$. Laboratories wastewater seems more toxic than production waste. In this connection, (Li et al., 1991) reported that the higher the content of algal chlorophyll a in the water, the more effective the removal of nitrogen and phosphorus from the water. Since the highest chlorophyll a content was observed in $0.5 \%$ for waste I and $40 \%$ conc. for waste II but all are still less than control value, these concentrations were selected to be used in all the following experiments in this investigation. Dry weight have similar trend of chlorophyll a for both types of wastes. 
Table 1: Some characteristics of pharmaceutical wastes before and after filtration

\begin{tabular}{|c|c|c|c|c|}
\hline \multirow{2}{*}{$\begin{array}{c}\text { Parameter } \\
\mathrm{mgL}^{-1} \text { except for } \mathrm{pH}\end{array}$} & \multicolumn{2}{|c|}{$\begin{array}{c}\text { Waste I } \\
\text { (Laboratories) }\end{array}$} & \multicolumn{2}{|c|}{$\begin{array}{c}\text { Waste II } \\
\text { (Production) }\end{array}$} \\
\hline & Raw waste & $\begin{array}{c}\text { After } \\
\text { neutralization } \\
\text { and } \\
\text { filtration } \\
\end{array}$ & Raw waste & $\begin{array}{c}\text { After } \\
\text { neutralization } \\
\text { and } \\
\text { filtration }\end{array}$ \\
\hline Temperature & $25^{\circ} \mathrm{C}$ & $25^{\circ} \mathrm{C}$ & $25^{\circ} \mathrm{C}$ & $25^{\circ} \mathrm{C}$ \\
\hline Colour & Colorless & Colorless & Orange & Orange \\
\hline $\mathrm{pH}$ & 10.3 & 7.0 & 7.4 & 7.0 \\
\hline Total Solids (TS) & 12900 & 3382 & 18300 & 4675 \\
\hline $\begin{array}{l}\text { Total dissolved solids } \\
\text { (TDS) }\end{array}$ & 7900 & 3252 & 13300 & 4325 \\
\hline $\begin{array}{l}\text { Total suspended solids } \\
\text { (TSS) }\end{array}$ & 5000 & 130 & 5000 & 350 \\
\hline $\begin{array}{c}\text { Chemical Oxygen Demand } \\
\text { (COD) }\end{array}$ & 14624 & 7245 & 24286 & 13705 \\
\hline $\begin{array}{l}\text { Biological Oxygen Demand } \\
\text { (BOD) }\end{array}$ & 790 & 580 & 1842 & 1223 \\
\hline Calcium $\left(\mathrm{Ca}^{++}\right)$ & 17 & 10 & 395 & 101.22 \\
\hline Chlorides $\left(\mathrm{Cl}^{-}\right)$ & 570 & 143.5 & 14 & 3.5 \\
\hline Sulphates $\left(\mathrm{SO}_{4}{ }^{--}\right)$ & 2540 & 390 & 8.5 & 2.6 \\
\hline Ammonia $\left(\mathrm{NH}_{3}\right)$ & 693 & 450 & 43.6 & 39.67 \\
\hline Phosphorus (P) & 8.5 & 5.35 & 11.8 & 6.9 \\
\hline
\end{tabular}

In waste I treatments the highest protein value (Table 2) was recorded at $0.5 \%$ conc. $\left(25.97 \mathrm{mgL}^{-1}\right)$. In waste II, the production of protein was favored by increase in waste concentration up to $40 \%$, it recorded $\left(22.74 \mathrm{mgL}^{-1}\right)$ but all values are still more than control value. Total carbohydrates accumulation by Phormidium fragile culture was decreased by increase in WI concentrations till it reached $\left(48.89 \mathrm{mgL}^{-1}\right)$ at $4 \%$ conc. In WII treatments, there was an increase in Egyptian J. of Phycol. Vol. 20, 2019

- 129 - 
total carbohydrates content up to $60 \%$ conc. $\left(82.95 \mathrm{mgL}^{-1}\right)$. In both wastes all recorded values are still less than control values grown on BG11 medium, still remain total carbohydrates in WII was higher than in WI cultures.

Table 2: Effect of different pharmaceutical wastewaters on chlorophyll a content, dry weight, protein and total carbohydrate contents of Phormidium fragile after 10 days incubation. Data are average of three replicates; each value represents the mean \pm S.D.

\begin{tabular}{|c|c|c|c|c|}
\hline $\begin{array}{c}\text { Waste I conc. } \\
(\%) \\
\end{array}$ & $\begin{array}{c}\text { Chlorophyll a } \\
\text { content } \\
\mu \mathrm{gL}^{-1} \\
\end{array}$ & $\begin{array}{c}\text { Dry weight } \\
\text { mgL }^{-1} \\
\end{array}$ & $\begin{array}{c}\text { Protein content } \\
\mathbf{m g L}^{-1} \\
\end{array}$ & $\begin{array}{c}\text { Total } \\
\text { carbohydrate } \\
\text { content } \\
\text { mgL }^{-1} \\
\end{array}$ \\
\hline $\begin{array}{c}\text { Control } \\
(0.0)\end{array}$ & $2270.33 \pm 08.50^{f}$ & $833.33 \pm 15.28^{f}$ & $14.02 \pm 01.58^{\mathrm{a}}$ & $98.90 \pm 07.05^{\mathrm{c}}$ \\
\hline 0.5 & $2026.33 \pm 07.09^{\mathrm{e}}$ & $420.00 \pm 10.00^{\mathrm{e}}$ & $25.97 \pm 00.91^{\mathrm{d}}$ & $61.74 \pm 03.71^{\mathrm{b}}$ \\
\hline 1 & $1793.00 \pm 10.82^{\mathrm{d}}$ & $366.67 \pm 05.77^{\mathrm{d}}$ & $21.78 \pm 01.75^{\mathrm{c}}$ & $59.16 \pm 02.15^{\mathrm{b}}$ \\
\hline 2 & $1547.33 \pm 07.23^{\mathrm{c}}$ & $340.00 \pm 10.00^{\mathrm{c}}$ & $18.43 \pm 00.72^{b}$ & $57.43 \pm 01.60^{\mathrm{b}}$ \\
\hline 3 & $1455.67 \pm 09.45^{\mathrm{b}}$ & $306.67 \pm 05.77^{\mathrm{b}}$ & $14.18 \pm 02.00^{\mathrm{a}}$ & $55.63 \pm 02.01^{\mathrm{b}}$ \\
\hline 4 & $1316.00 \pm 08.19^{\mathrm{a}}$ & $283.33 \pm 05.77^{\mathrm{a}}$ & $13.45 \pm 01.72^{\mathrm{a}}$ & $48.89 \pm 03.11^{\mathrm{a}}$ \\
\hline \multicolumn{5}{|l|}{$\begin{array}{c}\text { Waste II conc. } \\
(\%)\end{array}$} \\
\hline $\begin{array}{c}\text { Control } \\
(0.0)\end{array}$ & $2270.33 \pm 08.50^{\mathrm{f}}$ & $833.33 \pm 15.28^{\mathrm{d}}$ & $14.02 \pm 01.58^{\mathrm{a}}$ & $98.90 \pm 07.05^{\mathrm{d}}$ \\
\hline 10 & $1966.00 \pm 10.44^{\mathrm{a}}$ & $346.67 \pm 05.77^{\mathrm{a}}$ & $15.97 \pm 00.12^{\mathrm{ab}}$ & $53.61 \pm 02.21^{\mathrm{a}}$ \\
\hline 20 & $2157.33 \pm 10.60^{c}$ & $413.33 \pm 11.55^{\mathrm{b}}$ & $18.73 \pm 00.77^{\mathrm{b}}$ & $59.01 \pm 02.82^{\mathrm{a}}$ \\
\hline 40 & $2203.67 \pm 14.57^{\mathrm{e}}$ & $493.33 \pm 15.28^{c}$ & $22.74 \pm 01.63^{c}$ & $69.45 \pm 02.32^{\mathrm{b}}$ \\
\hline 60 & $2180.00 \pm 11.36^{\mathrm{d}}$ & $426.67 \pm 05.77^{\mathrm{b}}$ & $18.09 \pm 01.74^{\mathrm{b}}$ & $82.95 \pm 02.86^{\mathrm{c}}$ \\
\hline 80 & $2084.67 \pm 06.66^{\mathrm{b}}$ & $340.00 \pm 10.00^{\mathrm{a}}$ & $16.20 \pm 02.01^{\mathrm{ab}}$ & $65.56 \pm 01.97^{\mathrm{b}}$ \\
\hline Initial & $1230.33 \pm 05.86$ & $71.83 \pm 02.21$ & $12.62 \pm 00.65$ & $27.02 \pm 01.21$ \\
\hline
\end{tabular}

Means marked with the same superscript letters are not-significant $(\mathrm{P}>0.05)$, whereas others with different superscript letters are significant $(\mathrm{P}<0.05)$. 
From the above mentioned experiment, the selected concentrations $(0.5 \%$ for waste I and $40 \%$ for waste II) were incubated in optimum growth conditions with and without inoculation with Phormidium fragile. The microalgal efficiency for removing ammonia, phosphorus and reduction of COD and BOD from pharmaceutical wastewaters at certain concentrations was presented in (Table 3). The results demonstrated that removal percentage of ammonia, phosphorus, COD and BOD were higher after microalgal treatment than treatments without microalga indicating effective role of Phormidium fragile in removal process. In the above parameters except phosphorus, percentage removal was higher in Pharmaceutical production waste (WII) than laboratories waste (WI). Whereas ammonia percentage removal by Phormidium in WI was $51.56 \%$ and $58.89 \%$ in WII while it was $22.67 \%$ for WI $0.5 \%$ and $25.02 \%$ for WII $40 \%$ in treatment without algae which is in agreement with Lau et al. (1995), they found that maximum ammonia removal percentage in the control (without algae) was less than $20 \%$. Microalgae mainly use inorganic nitrogen as a nutrient source for their cell synthesis and ammonia is the first preferable form of inorganic nitrogen for microalgae. Tam and Wong (2000) found that the reductions in wastewater $\mathrm{NH}_{4}{ }^{+}-\mathrm{N}$ concentrations in all algal bioreactors were significantly better than those without algae, suggesting that uptake of ammonium and assimilation into algal biomass are essential processes. Dubey et al. (2011) investigated the potential degradation of industrial effluents by environmental species of cyanobacteria isolated from the pharmaceutical industries. Results indicated the potential of natural resources as efficient agents for pollution control.

In the results demonstrated in (Table 3), phosphorus was efficiently reduced in both wastes WI $0.5 \%$ conc. and WII $40 \%$ conc. by $66.67 \%$ and $61.23 \%$ respectively. Also COD was reduced from 922 to $445 \mathrm{mgL}^{-1}$ and from 5460 to $2481.33 \mathrm{mgL}^{-1}$ for laboratories WI and production WII wastes respectively. Also BOD was reduced from 224 to $141 \mathrm{mgL}^{-1}$ and from 680 to 273 $\mathrm{mgL}^{-1}$ for WI and WII with algae respectively, comparing with treatment without algae, this indicates the role of microalgal cells in the treatment. In previous study reported by Kshirsagar (2010), COD of herbal and bulk drug pharmaceutical wastewaters was reduced from 13,090 to $3,927 \mathrm{mgL}^{-1}$ and from 34,452 to 13,333 
$\mathrm{mgL}^{-1}$ respectively whereas $\mathrm{BOD}$ of herbal and bulk drug pharmaceutical wastewater was reduced from 7,420 to $2,003 \mathrm{mgL}^{-1}$ and from 15,840 to 5,608 $\mathrm{mgL}^{-1}$ respectively.

Table 3: Analysis of filtered pharmaceutical WI and WII at certain concentrations before and after inoculation with Phormidium fragile for 10 days incubation. Data are average of three replicates; each value represents the mean \pm S.D.

\begin{tabular}{|c|c|c|c|c|c|c|}
\hline \multirow{2}{*}{$\begin{array}{c}\text { Parameter } \\
\text { mgL }^{-1}\end{array}$} & \multicolumn{3}{|c|}{ WI $0.5 \%$ conc. } & \multicolumn{3}{|c|}{ WII $40 \%$ conc. } \\
\hline & Initial & $\begin{array}{c}\begin{array}{c}\text { Without } \\
\text { algae }\end{array} \\
\end{array}$ & $\begin{array}{c}\text { After algal } \\
\text { treatment }\end{array}$ & Initial & $\begin{array}{c}\begin{array}{c}\text { Without } \\
\text { algae }\end{array} \\
\end{array}$ & $\begin{array}{c}\text { After algal } \\
\text { treatment }\end{array}$ \\
\hline Ammonia & $\begin{array}{c}2.25 \\
\pm 0.03\end{array}$ & $\begin{array}{c}1.74 \\
\pm 0.05\end{array}$ & $\begin{array}{c}1.09 \\
\pm 0.07\end{array}$ & $\begin{array}{l}11.87 \\
\pm 0.31\end{array}$ & $\begin{array}{c}8.90 \\
\pm 0.34\end{array}$ & $\begin{array}{c}4.88 \\
\pm 0.10\end{array}$ \\
\hline \% Removal & ---- & 22.67 & 51.56 & ---- & 25.02 & 58.89 \\
\hline Phosphorus & $\begin{array}{c}0.03 \\
\pm 0.01\end{array}$ & $\begin{array}{c}0.02 \\
\pm 0.01\end{array}$ & $\begin{array}{c}0.01 \\
\pm 0.01\end{array}$ & $\begin{array}{c}2.76 \\
\pm 0.05\end{array}$ & $\begin{array}{c}2.04 \\
\pm 0.07\end{array}$ & $\begin{array}{c}1.07 \\
\pm 0.08\end{array}$ \\
\hline \% Removal & ---- & 33.33 & 66.67 & ---- & 26.09 & 61.23 \\
\hline COD & $\begin{array}{l}922.00 \\
\pm 03.61\end{array}$ & $\begin{array}{l}690.00 \\
\pm 09.54\end{array}$ & $\begin{array}{l}445.00 \\
\pm 07.00\end{array}$ & $\begin{array}{c}5460.00 \\
\pm 12.77\end{array}$ & $\begin{array}{c}3983.00 \\
\pm 14.53\end{array}$ & $\begin{array}{c}2481.33 \\
\pm 12.06\end{array}$ \\
\hline$\%$ Reduction & ---- & 25.16 & 51.74 & ---- & 27.05 & 54.55 \\
\hline BOD & $\begin{array}{l}224.00 \\
\pm 08.72\end{array}$ & $\begin{array}{l}150.00 \\
\pm 07.21\end{array}$ & $\begin{array}{l}141.00 \\
\pm 06.24\end{array}$ & $\begin{array}{l}680.00 \\
\pm 09.54\end{array}$ & $\begin{array}{l}393.00 \\
\pm 08.72\end{array}$ & $\begin{array}{l}273.00 \\
\pm 07.00\end{array}$ \\
\hline$\%$ Reduction & ---- & 33.04 & 37.05 & ---- & 42.21 & 59.85 \\
\hline
\end{tabular}

Nutrient starvation is a stressful condition for algae that changes biochemical compounds of biomass (Malakootian et al., 2015). The effect of Nstarvation for Phormidium cells and a series of cyanobacterial suspension inocula on nutrient removal from WI and WII was investigated. The data generated in the present study (Fig.1) revealed that removal efficiency of ammonia from WI $0.5 \%$ 
conc. by Phormidium fragile ranged from $16-100 \%$ for unstarved cells, while it was $28.44-100 \%$ for starved cells and for WII $40 \%$ conc. ranged from 48.86 $84.92 \%$ for unstarved cells, while it was $51.05-87.28 \%$ for starved cells. Increase in algal dose caused significant decrease in ammonia content from both pharmaceutical wastewaters in both unstarved and starved cell cultures and reached maximum removal percentage at $40 \mathrm{ml}$ algal dose, it was $100 \%$ in WI and $87.28 \%$ in WII starved cells. Lee et al. (2016) reported that the increased algal biomass was accompanied by ammonia decrease during the first 5 days which indicates that algae take up ammonia for biomass production and as an energy source leading to increased nitrogen removal.

In the current study, Phosphorus conc. in the wastewaters exhibited high decrease with increase in algal inoculum of both unstarved, starved cultures (Fig.1). Phosphorus disappeared completely at higher algal doses $(30 \mathrm{ml}$ and 40 $\mathrm{ml}$ ) recording $100 \%$ percentage removal in both unstarved and starved cells. These data are in agreement with (Tam and Wong, 1989), who reported an increase in phosphorus removal with increasing inoculum dose of algal cells. Amiri and Ahmadi (2019) reported that phosphate removal during phycoremediation is due to the utilization of phosphorus for algal growth. The phosphorus, which is used in the algal cells mainly for the production of phosphorous-containing compounds such as adenosine triphosphate (ATP) and nicotinamide adenine dinucleotide phosphate-oxidase (NADPH). Rao et al. (2011) suggested that the chemical stripping of phosphorus may be regarded as an advantageous side-effect of the algal growth, with enhanced phosphorus removal as a result.

COD determined at the end of incubation period generally exhibited reduction with increase in algal inoculums (Fig.1). Percentage reduction of COD was $72.56 \%$ and $71.98 \%$ at higher starved algal dose for WI and WII respectively while it recorded percentage reduction $65.62 \%$ of initial conc. for unstarved algal cells for WI and $68.58 \%$ for WII. In the contrary, Lau et al. (1995) reported that Chlorella vulgaris with four initial inoculum sizes when applied to primary treated sewage, there were no significant differences between the four algal cultures in terms of COD removal.

Egyptian J. of Phycol. Vol. 20, 2019 

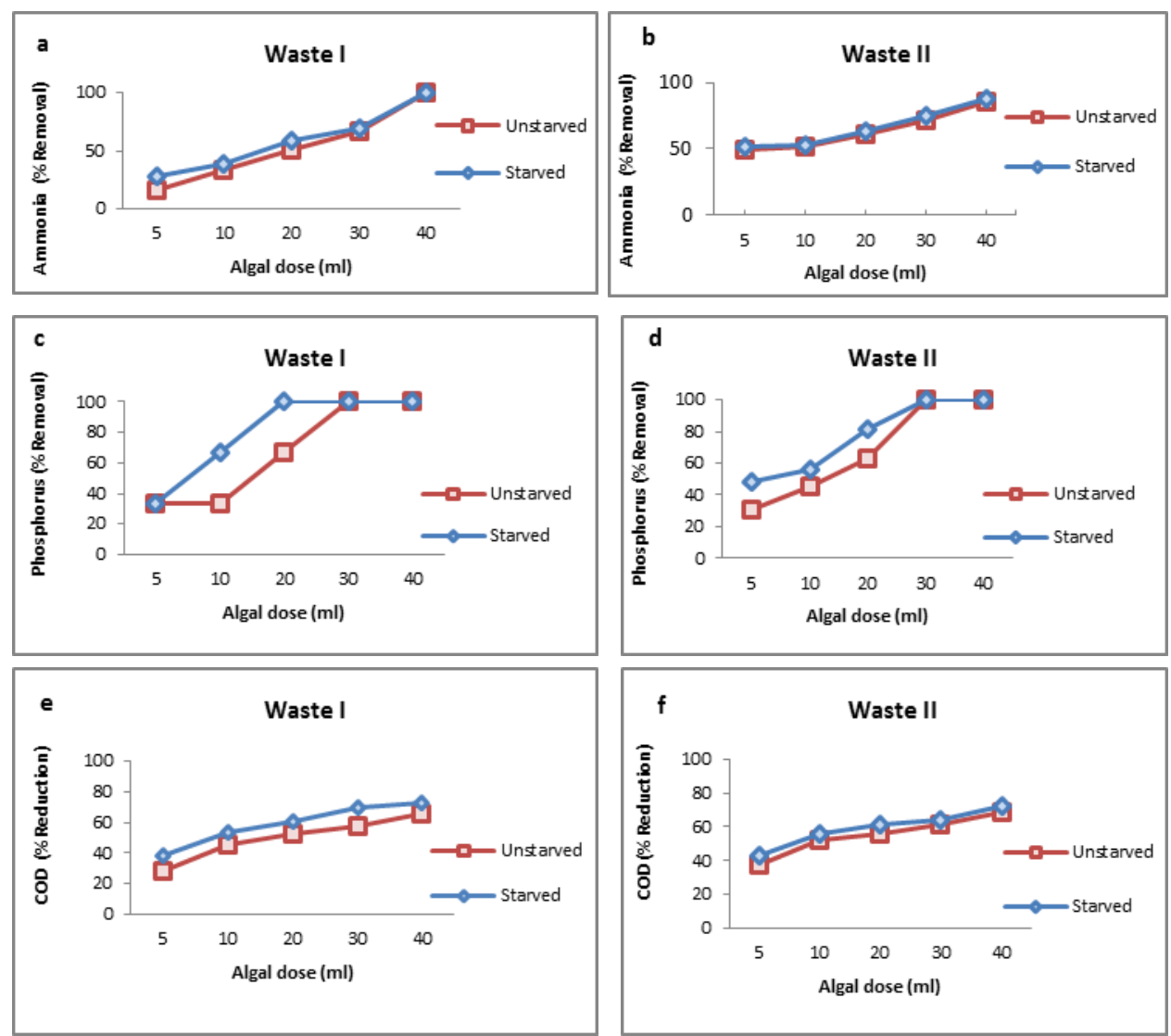

Fig. 1: Percentage removal of ammonia, phosphorus and COD in pharmaceutical wastewaters I ( $0.5 \%$ conc.) and II (40 \% conc.) using different doses of starved and unstarved algal cells after 10 days incubation in optimum growth conditions.

The data presented in (Fig. 2) revealed that chlorophyll a content and dry weight values of Phormidium cells in both wastes (WI $0.5 \%$ conc. and WII $40 \%$ conc.) increased significantly by increasing the algal dose of both unstarved and starved Phormidium cells showing higher contents of chlorophyll a in the starved treatments than the unstarved. Chlorophyll a content was $\left(3756.67 \mu \mathrm{gL}^{-1}\right)$ and 
$\left(3690.00 \mu \mathrm{gL}^{-1}\right)$ at $40 \mathrm{ml}$ algal dose in starved Phormidium cells for WI $0.5 \%$ and WII $40 \%$ respectively. The same trend was demonstrated for dry weight data which was highly increased with increasing algal inoculum to reach highest values (546.67 $\mathrm{mgL}^{-1}$ and $480.00 \mathrm{mgL}^{-1}$ ) at $40 \mathrm{ml}$ unstarved and starved Phormidium cells for WI $0.5 \%$ while recorded $\left(626.67 \mathrm{mgL}^{-1}\right.$ and $\left.533.33 \mathrm{mgL}^{-1}\right)$ at $40 \mathrm{ml}$ unstarved and starved algal cells for WII $40 \%$ at the end of incubation period. The data presented in (Fig.2) also revealed that protein production by Phormidium cultures was favored with increase in algal dose to reach the highest yields $\left(45.88 \mathrm{mgL}^{-1}\right.$ and $\left.49.81 \mathrm{mgL}^{-1}\right)$ at $40 \mathrm{ml}$ unstarved and starved cells for WI $0.5 \%$ while reached $\left(29.79 \mathrm{mgL}^{-1}\right.$ and $\left.34.80 \mathrm{mgL}^{-1}\right)$ at $40 \mathrm{ml}$ unstarved and starved for WII $40 \%$. In addition, increase in the protein content in starved algal cells was more than unstarved for both waste types. The same trend was demonstrated for accumulation of total carbohydrates, since the highest values $\left(76.32 \mathrm{mgL}^{-1}\right.$ and $93.52 \mathrm{mgL}^{-1}$ ) were recorded at $40 \mathrm{ml}$ unstarved and starved Phormidium cells for WI $0.5 \%$ while recorded $\left(127.57 \mathrm{mgL}^{-1}\right.$ and $\left.156.77 \mathrm{mgL}^{-1}\right)$ at $40 \mathrm{ml}$ unstarved and starved for WII $40 \%$. Nitrogen starvation was also employed to trigger the accumulation of lipid and carbohydrate (Ho et al., 2012). It is clear that in contrary to protein the production of total carbohydrates by Phormidium cultures in waste II at moderate and higher doses far exceeded that accumulated in waste I cultures.

Mandal and Mallick (2009) demonstrated that cultivation under nitrogen deficient conditions leads to a sharp increase in the lipid or carbohydrate content, because the condition of nitrogen- depletion probably transforms protein or peptides to lipids or carbohydrates. Therefore, the condition of nitrogen starvation causes an enhancement of energy-rich products, such as lipids and carbohydrates. Quantities of the available nitrogen in the culture directly alter cell growth. Nitrogen limitation in the microalgae culture can reduce growth and biomass productivity although they increase production of carbohydrates and lipids (Daliry et al., 2017).Worthy to be noted that, in the present study the protein and total carbohydrate contents of Phormidium cells in certain concentrations of both wastes tended to increase progressively by intensifying the algal dose with higher value in the starved than the unstarved algal dose. Salama and Shabana (1989) found that nitrogen starvation of Phormidium fragile for 36- 44 hrs leads to elevation in the total carbohydrate and protein accumulation by the organism. 

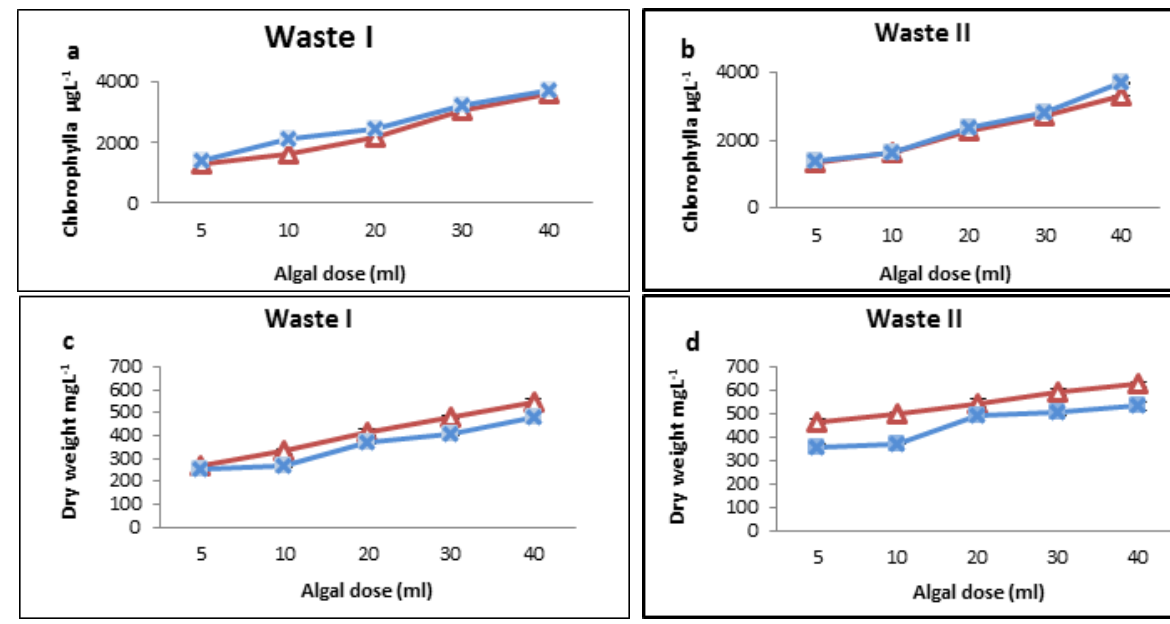

Algal dose (ml)
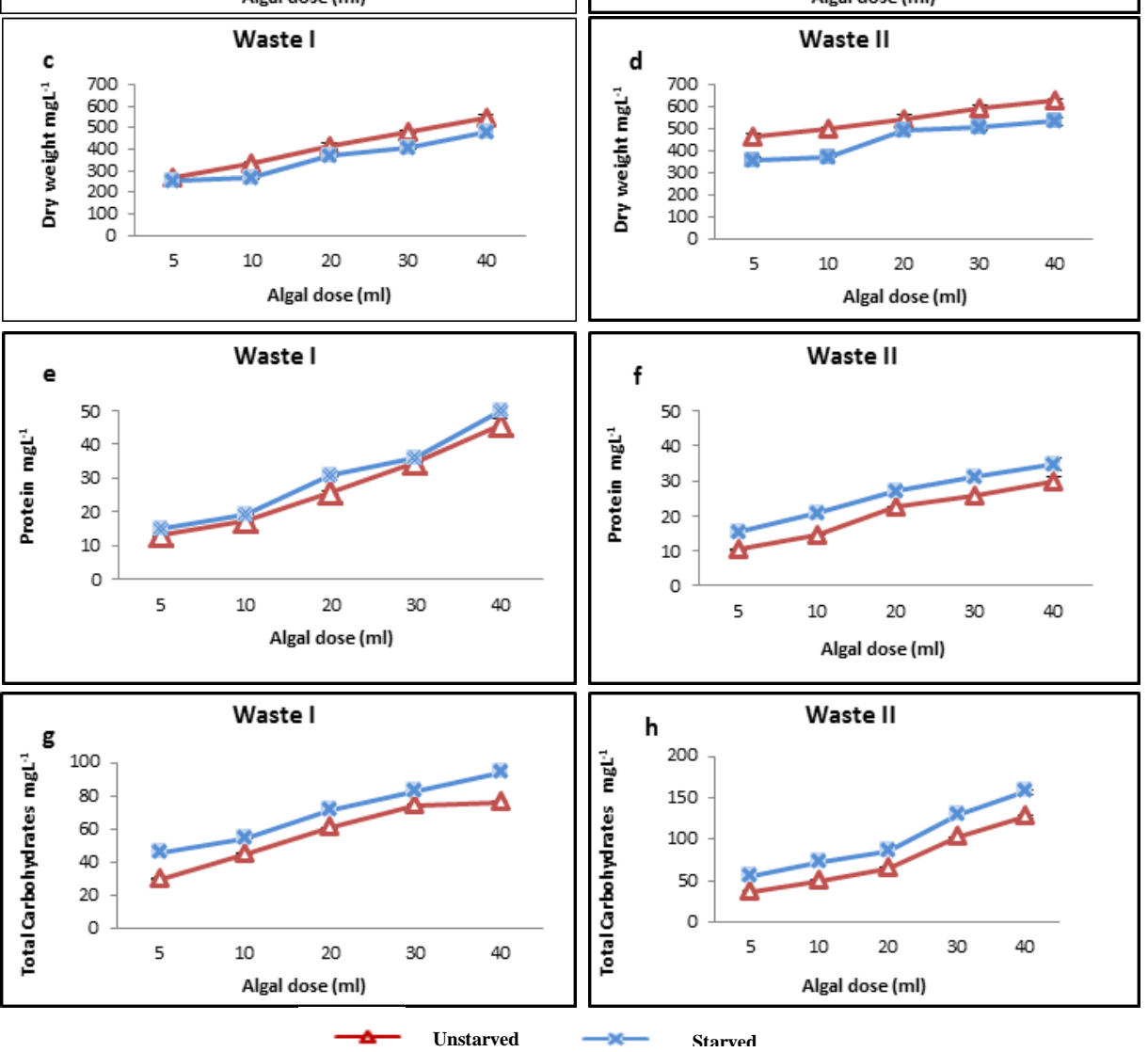

Fig. 2: Effect of pharmaceutical waste I ( $0.5 \%$ conc.) and waste II (40 \% conc.) on chlorophyll a content, dry weight, Protein and total carbohydrate contents of starved and unstarved Phormidium fragile cells with different doses after 10 days incubation. 
An excessive cell density could limit the light penetration into the water column and thus reduce the growth, particularly in scarcely mixed cultures (Campos-Rudin and Silva-Benavides, 2018).

Apart from photosynthetic and chemosynthetic assimilation by microalgae, $\mathrm{N}$ and $\mathrm{P}$ removal from wastewaters are also affected by abiotic factors significantly. Therefore, the $\mathrm{N}$ and $\mathrm{P}$ removal in wastewater-based algae cultivation system were attributed to assimilation by microalgae as well as volatilization and precipitation caused by abiotic factors (Zhou, 2014). Culture growth depends on different factors such as light intensity, $\mathrm{pH}$, nutrients, carbon dioxide, mixing, and temperature. In wastewater, growth depends in part by the active nutrient uptake of the photosynthetic cells and their transformation into biomass (Voltolina et al., 2005). Regarding light intensity (Fig.3), it is relevant to notice that 2500 lux was the optimum light intensity for ammonia and phosphorus removal from both pharmaceutical wastewaters by Phormidium cultures $52.89 \%$ and $66.67 \%$ in WI and $59.14 \%$ and $62.32 \%$ in WII. Microalgae need light as an energy source to convert the absorbed water and $\mathrm{CO}_{2}$ into biomass through photosynthesis (Ozkurt, 2009). Nutrient removal can also be further increased by $\mathrm{NH}_{3}$ stripping or $\mathrm{P}$ precipitation due to the rise in the $\mathrm{pH}$ associated with photosynthesis (Larsdotter, 2006). Also the data in (Fig.3) revealed that the highest COD percentage reduction was in 2500 lux for WI $0.5 \%$ conc. and WII $40 \%$ conc. cultures (54.23\% and 54.92\%) respectively. Ho et al. (2012) observed in a study, the dependence of the specific growth rate of Scenedesmus obliquus on light intensity under continuous illumination. It was clearly seen that the specific growth rate increased dramatically with rising light intensity and then it gradually leveled off as the light intensity continued to rise. Suggesting that excessive illumination would inhibit the biomass production and $\mathrm{CO}_{2}$ fixation ability, which is commonly recognized as the photo-inhibition effect.

Temperature is another important factor in the growth of microalgae and directly influences the biochemical processes, including photosynthesis, in the algal cell factory. Each species has its own optimal growth temperature. Increasing temperature to the optimum range exponentially increases algal growth, but an increase or decrease in the temperature beyond the optimal point retards or even stops algae growth and activity (Bechet $\boldsymbol{e t}$ al., 2017). 

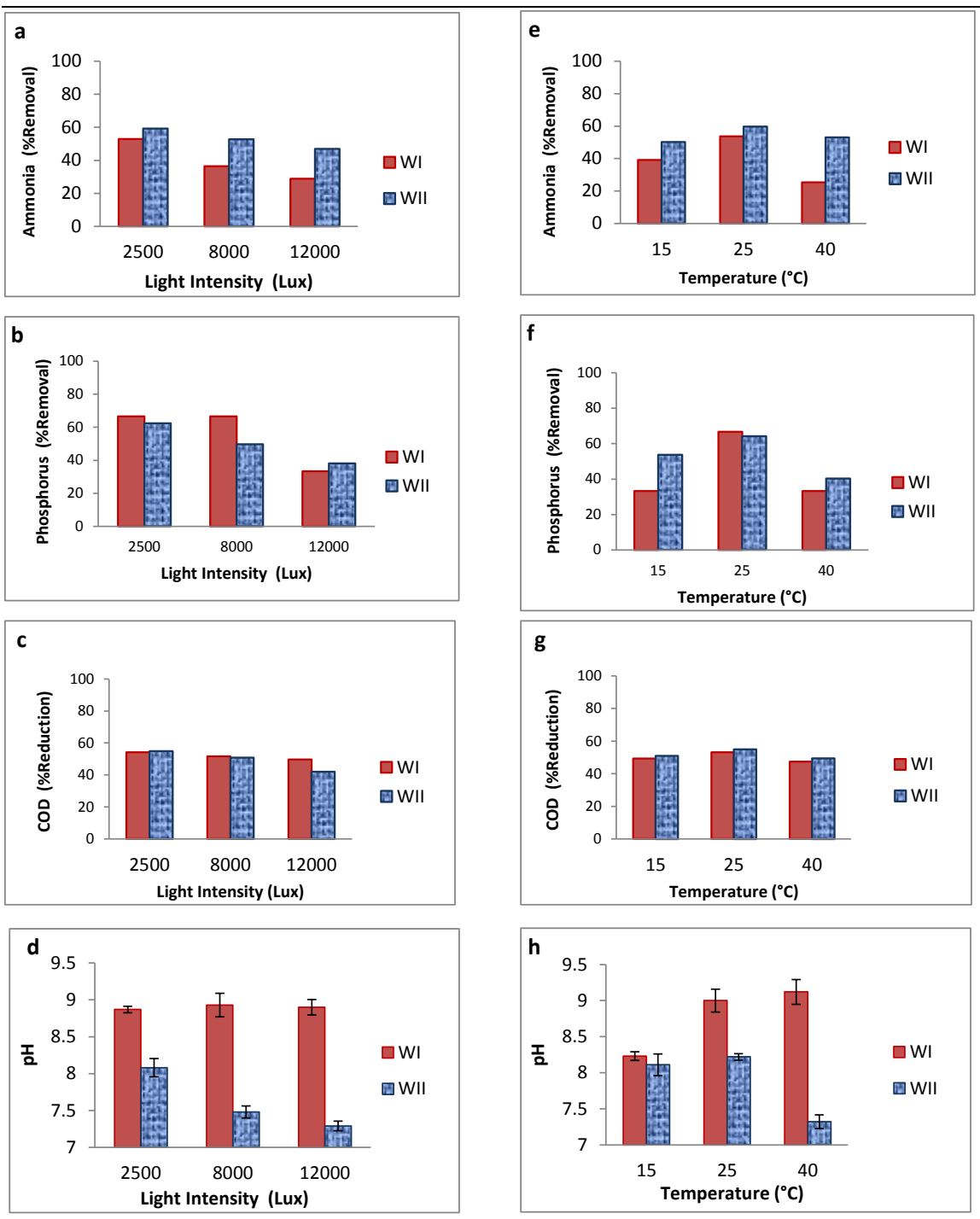

Fig. 3: Effect of light intensity and temperature on $\mathrm{pH}$, ammonia and phosphorus removal and COD reduction from pharmaceutical waste I $(0.5 \%$ conc.) and waste II (40\% conc.) by Phormidium fragile after 10 days incubation. 
In the current study, maximum ammonia and phosphorus removal were recorded at $25 \pm 2^{\circ} \mathrm{C}$ for both wastes where it was $53.78 \%$ and $66.67 \%$ in WI and $59.65 \%$ and $64.13 \%$ in WII. Azeez (2010) reported that the highest removal of nitrogen and phosphorus is achieved at temperature $30^{\circ} \mathrm{C}$ and they were $92 \%$, $89 \%$ respectively. The data recorded in (Fig.3) showed that maximum percentage reduction of COD was at $25 \pm 2^{\circ} \mathrm{C}(53.15 \%$ and $55.01 \%$ of initial $)$ was recorded at such degree for WI and WII respectively. On the other hand minimum percentage removal of COD was attained at $40{ }^{\circ} \mathrm{C}(47.47 \%$ and $49.48 \%)$ for WI and WII which is in agreement with (Azeez, 2010), who found that at temperature $30^{\circ} \mathrm{C}$ there is a decrease in COD with a removal efficiency $88 \%$. While at temperature higher than $30^{\circ} \mathrm{C}$ the removal efficiency of COD decreases because the activity of microorganism becomes lower after this temperature which means that ability to remove pollutants decreases. However, in optimum temperature algal growth would not be affected by high light intensities (Borowitzka, 1998). Microalgae can tolerate the temperature range of $16-27^{\circ} \mathrm{C}$ and the temperature lower than 16 ${ }^{\circ} \mathrm{C}$ slow down the growth whereas higher than $35^{\circ} \mathrm{C}$ is harmful for the number of species (Butterwick et al. 2005).

The use of free cells is rather rare in comparison to immobilized cells, since immobilization of cells offers various advantages and the process is cost effective (Vijayakumar, 2012). The immobilized cells have many advantages in the bioremediation pollutants in wastewaters: nontoxic, transparent for light, stable in growth medium, a high population density can be entrapped in a small volume, it provides microorganisms protection against toxicity of the pollutants in wastewater, the minimization of inhibition and toxicity to microbial cells by diffusional constrains as well as avoiding cell harvesting problems. The immobilized cells can be reused for successive applications and this reduce the costs because it can remain viable for long time, it can be stored for long periods without loss of their activities for bioremediation (Mallick, 2002; Quek et al., 2006; Bikram et al., 2014). Protection against toxicity in immobilized cells is reported in different works. Immobilized cells are characterized by its stability because the cells are entrapped in the matrix and are protected from toxic compounds in wastewater; therefore, they have a higher efficiency for the removal of nutrients (Cassidy et al., 1996; EL-Sheekh et al., 2016), dye (Revathi et al., 2017), and heavy metals (EL-Sheekh and Mahmoud 2017) than free cells. 
Despite these advantages, alginate beads have some disadvantages such as their low mechanical stability for long term use in bioreactor; more over calcium alginate gels are disrupted by phosphate ions (Boominathan, 2005; Vijayakumar and Manoharan, 2012).

In the present study, initial ammonia contents were $(2.25,11.87$ and 7.33 $\mathrm{mgL}^{-1}$ ) in waste I, waste II and their mixture. Ammonia content was significantly decreased in all treatments (Table 4) either in free or immobilized algal cells when incubated in waste I and waste II giving removal percentage $(53.33 \%$ and $59.73 \%)$ in free cells. Removal percentage in all treatments increased $(72.44 \%$, $89.22 \%$ and $69.03 \%$ ) for WI, WII and their mixture (1:1) which means that Phormidium in alginate beads was more efficient than free algal cells in the ammonia removal process. Higher nutrient removal efficiency has been recorded in the immobilized algal biomass than the freely suspended cells of the same algal species (De la Noüe and Proulx, 1988; Abdel Hameed, 2002). Moreover nitrogen starvation of algal cells before immobilization recorded the highest value of ammonia removal $(80 \%, 91.15 \%$ and $79.54 \%)$ for WI, WII and their mixture, respectively. The success in employing immobilized microalgae for wastewater treatment depends upon many factors, including algal species, immobilization matrix, cell and bead concentration, bead morphology, etc. (Tam and Wong, 2000). This is in agreement with (Abdel Hameed, 2007), who reported that $C$. vulgaris immobilized in alginate beads were more effective in removing $\mathrm{N}$ and $\mathrm{P}$ from wastewater than blank alginate beads. (Table 4) showed that most efficient ammonia removal occurs in the treatments with starved immobilized Phormidium cultures for WI, WII and their mixture after 10 days incubation period.

Regarding to Phosphorus content, it was decreased in all treatments. Data in (Table 4) showed that immobilized Phormidium was more efficient than free algal cells in the phosphorus removal since percentage removal reached $100 \%$, $73.91 \%$ and $63.33 \%$ for WI, WII and their mixture where as it was $66.67 \%$ and $63.41 \%$ for WI and WII free cultures. Starvation of algal cells before immobilization recorded the highest values of phosphorus removal $(100.00 \%$, $88.04 \%$ and $84.00 \%)$. 
Tam and Wong (2000) reported $78 \%$ ammonium and $94 \%$ phosphate removal efficiencies with immobilized $C$. vulgaris, entrapped in calcium alginate beads, compared to the $40 \%$ ammonium and $59 \%$ phosphate removal with free cells. Lau et al. (1997) also observed significantly higher ammonium (95\%) and phosphate (99\%) removal efficiencies for $C$. vulgaris cells immobilized in alginate beads relative to their free counterparts.

Initial COD content in WI $\left(922.00 \mathrm{mgL}^{-1}\right)$, in WII $\left(5460.00 \mathrm{mgL}^{-1}\right)$ and their mixture (3191.67 $\left.\mathrm{mgL}^{-1}\right)$ decreased recording higher percentage reduction in Phormidium alginate beads treatments. Starvation before immobilization increased reduction percentage of COD in all wastes tested recording $(60.48 \%$, $61.31 \%$ and $64.63 \%$ ) for WI, WII and their mixture, respectively. The lowest reduction percentages for ammonia, phosphorus and COD were observed in blank beads for all waste treatments indicating the role of algal cells in the process of bioremediation. The low efficiency of removal of COD in the blank beads flatphotobioreactor was due to the presence of a carboxyl functional group which binds to the organic material only (Singh et al., 2012). Lau et al. (1997) supported the idea that simple inorganic ions such as nitrate, ammonium and phosphate would be as freely available to immobilized algae as to their free counterparts, because nutrients must diffuse through the alginate pores to reach the algal cells. The higher phosphorus removal in immobilized cells may be directly related to the initial concentration of cells per $\mathrm{ml}$ of culture medium. The lower cells density may have caused a greater light diffusion and, thus, lower selfshading effect within cells. This could have allowed for greater cellular activity and consequently reach larger nutrients removal (Ruiz-Marin et al., 2010). It is worthy to mention that free algal cells were disintegrated in the mixture treatment giving no growth which means inhibitory effect of it when in a direct contact with the microalgal cells. The immobilization on alginates protects microorganisms from toxic substances, $\mathrm{pH}$, and temperature extremes (Lessel, 1994). It increases the rate of biodegradation of pollutants through increasing cell loading and this also improve the catalytic stability as well as the tolerance against toxic pollutants (Wang et al., 2007). From the present data it is clear that immobilized Phormidium was more efficient than free algal cells in the removal process where as nitrogen starvation before immobilization increased removal percentage of ammonia, phosphorus and COD. 
Table 4: Effect of immobilized starved and unstarved Phormidium fragile cells on ammonia and phosphorus removal and COD reduction from pharmaceutical wastewaters I, II and their mixture after 10 days incubation. Data are average of three replicates; each value represents the mean \pm S.D.

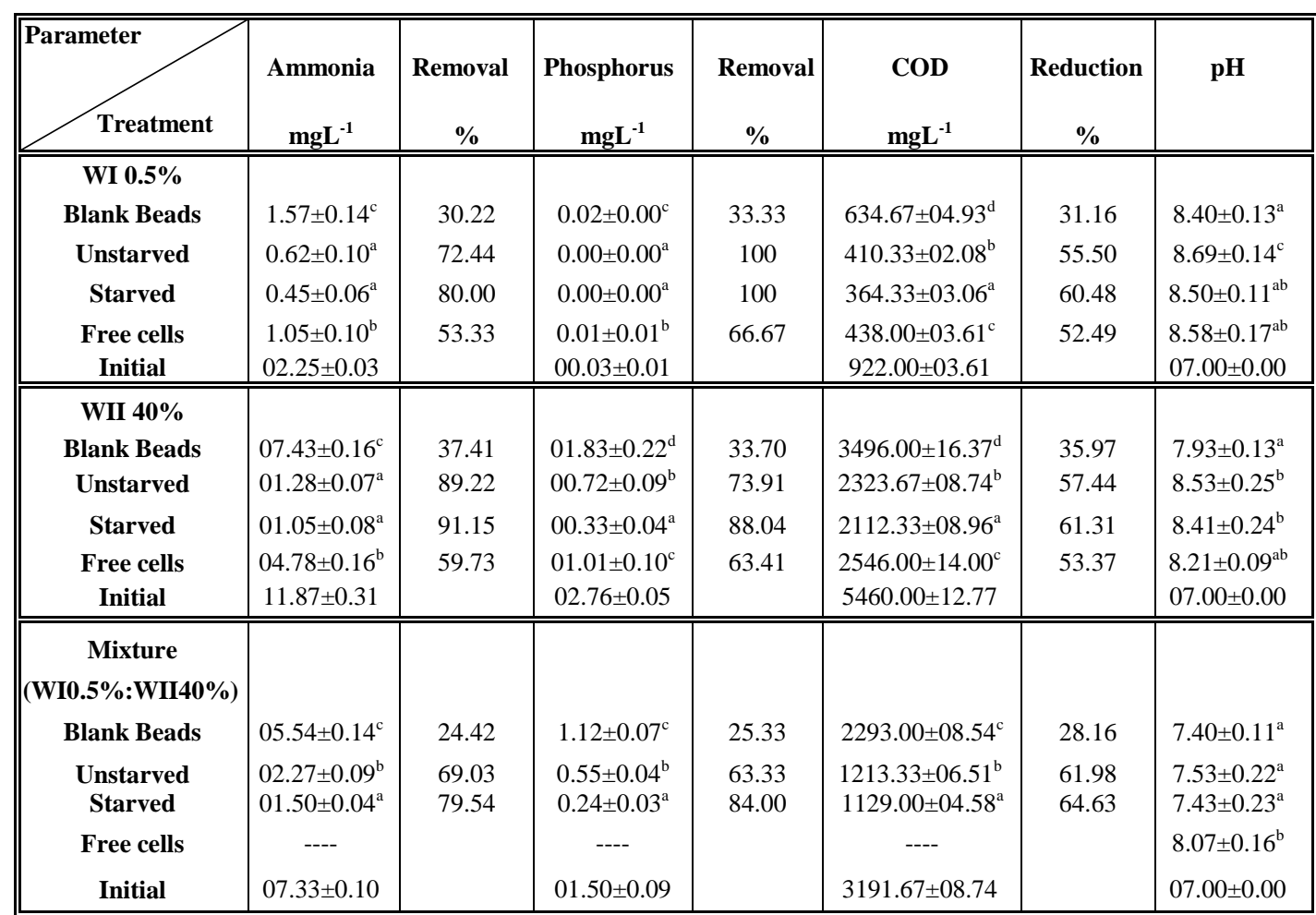

Means marked with the same superscript letters are not-significant $(\mathrm{P}>0.05)$, whereas others with different superscript letters are significant $(\mathrm{P}<0.05)$.

Data in (Fig.4) showed that repeated incubation of starved and unstarved Phormidium alginate beads in WI, WII and their mixture in a semi-continuous system for 5 consecutive cycles (10 days each) caused higher ammonia and 
phosphorus removal especially in the first three cycles with higher percentage removal in starved than unstarved beads treatments. After the third cycle percentage removal of ammonia and phosphorus began to decrease. Ammonia removal percentage reached $100 \%$ in waste I in both starved and unstarved beads where as it recorded $99.49 \%$ and $97.56 \%$ for waste II and for the mixture $97.82 \%$ and $94.54 \%$ in the second cycle. Phosphorus removal percentage reached $100 \%$ in starved WI in all cycles where as it reached $100 \%$ removal in cycle three for WII and mixture. Regarding to COD, higher percentage reduction was recorded especially in the first two cycles with higher percentage removal in starved than unstarved beads. The highest COD reduction percentage was obtained in the second cycle recording higher values in starved than unstarved Phormidium beads $(86.73 \%, 69.26 \%$ and $66.52 \%)$ for WI, WII and their mixture. These data are in agreement with (Cruz et al., 2013) who reported that degradation of beads is relatively slow; hence, there is sufficient time to efficiently remove nutrients by microbial agents immobilized inside the beads. Still the beads survived long enough to allow completion of the removal of phosphorus, ammonia from wastewater; the contaminants in the wastewater significantly reduced the mechanical strength of the beads. Faafeng et al. (1994) observed the degradation of sodium alginate beads, used for the immobilization of Selenastrum capricornutum, after keeping them in polluted wastewater with high phosphorous (P) and nitrogen $(\mathrm{N})$ content for longer than two weeks. This instability of alginate happens when the gels are in contact with cations that serve as chelating agents and anti-gelling cations, such as dissolved phosphorus, EDTA citrates, sodium bicarbonate, and several more (Moreira et al., 2006). Ruiz-Marin $\boldsymbol{e t}$ al. (2010) found that Scenedesmus obliquus when tested in semi-continuous mode was more effective in removing $\mathrm{N}$ and $\mathrm{P}$ for longer periods than batch cultures. Immobilized S. obliquus removed $97 \%$ and $90 \%$ of ammonium in AWI (Artificial wastewater immobilization) and UWI (Urban wastewater immobilization), respectively, during the first $48 \mathrm{~h}$. After $250 \mathrm{~h}$ the removal decreased to 30 and $10 \%$. A similar pattern was observed for phosphorous removal where $85 \%$ removal in AWI was maintained for four cycles, after which the system had a removal capacity of only $30 \%$. They concluded that practically the semicontinuous culture of $S$. obliquus does not appear to allow a sustainable culture to treat wastewater which is in contrary to our results. 
Increasing algal cells entrapped within the beads didn't cause any significant improvement in nutrient removal (Lau et al., 1997). On the contrary, superconcentrated cell stockings in the beads posed serious leakage problem (Robinson et al., 1986). The study of (Abdel Hameed, 2007), indicated that the beads concentrations in wastewater did not affect the efficiency of phosphate removal. Also phosphate might be precipitated as calcium phosphate due to the presence of calcium ions in the alginate matrix (Jimenez- Perez et al., 2004) and wastewater together with elevated $\mathrm{pH}$ values. Finally one can say that the immobilized cells either starved or unstarved showed greater efficiency for nutrient removal even after five repeated cycles. The present study recommended the upgrading of traditional operation systems to algal cell immobilization technique with low cost.

During the present study, $\mathrm{pH}$ levels increased initially and thereafter remained in the range 7.3 to 9.1 (Fig.3). Increase in $\mathrm{pH}$ during phycoremedation is the usual behavior of blue green algae which favors their growth (Promya et al., 2008). Increasing $\mathrm{pH}$ represent the indirect role of microalgae to improve the treatment process. High levels of $\mathrm{pH}$ alter the physicochemical environment of the wastewater and cause phosphate and metals precipitation, ammonia stripping and disinfection (Abdulsada, 2014). $\mathrm{pH}$ is considered as indicator of several biochemical activities, whose the photosynthesis and the biodegradation of the organic matter, the high $\mathrm{pH}$ values are attributed to higher photosynthetic rates of algae (Mahapatra et al., 2013). Microalgae species have different $\mathrm{pH}$ requirements. Chlorella vulgaris can grow in broad range of $\mathrm{pH}$ however the maximum growth rate and biomass productivities are reported at $\mathrm{pH}$ 9-10 (Daliry et al., 2017). 

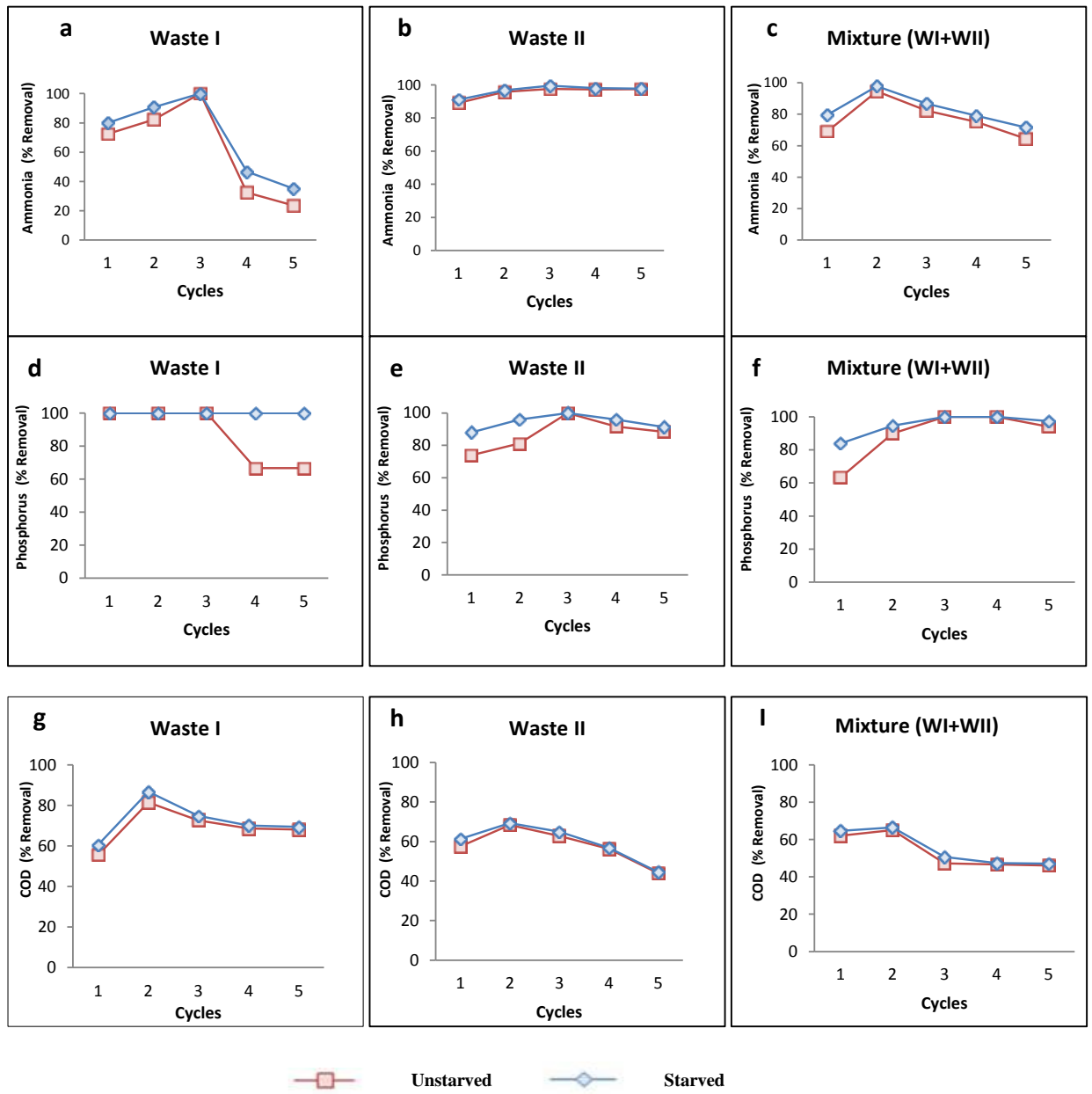

Fig. 4: Effect of repeated treatments of immobilized starved and unstarved Phormidium fragile cells on ammonia and phosphorus removal and COD reduction from pharmaceutical wastes I, II and their mixture (5 consecutive cycles, each cycle 10 days) incubation in a semi-continuous system. 


\section{Conclusion}

- If cyanobacterium Phormidium fragile is applied to natural discharge of pharmaceutical wastewater, it can utilize the pharmaceutical wastewater as nutrient source and will help in reducing the toxicity and facilitate recycling and reutilization of polluted water before discharging into surface aquatic systems providing a low cost, with no secondary pollution and naturally renewable technology.

- Starved Phormidium alginate beads are more effective in removing $\mathrm{N}$ and $\mathrm{P}$ from wastewater than unstarved and free cells or blank alginate beads.

- Repeated incubation of immobilized starved and unstarved Phormidium beads in WI, WII and their mixture in a semi-continuous system (5 consecutive cycles) caused increase in nutrients percentage removal which gives a promise to upgrading immobilization technique for wastewater treatment with low cost.

\section{References}

Abdel Hameed, M. S. (2002). Effect of Immobilization on growth and photosynthesis of the green alga Chlorella vulgaris and its efficiency in heavy metals removal. Bull. Fac. Sci. Assiut Uni., 31(1-D): 233-240.

Abdel Hameed, M. S. (2007). Effect of algal density in bead, bead size and bead concentrations on wastewater nutrient removal. African Journal of Biotechnology., 6 (10):1185-1191.

Abdulsada, Z. K. (2014). Evaluation of microalgae for secondary and tertiary wastewater treatment. Master Thesis, Ottawa-Carleton Institute for Environmental Engineering Ottawa, Ontario, pp. 114.

Amin, A.; Naik, A. T. R.; Azhar, M. and Nayak, H. (2013). Bioremediation of different waste waters-a review. Cont. J. Fish. Aquat. Sci., 7(2):7-17. 
Amiri, R. and Ahmadi, M. (2019). Treatment of wastewater in sewer by Spirogyra sp. green algae: effects of light and carbon sources. Water and Environment Journal., 33: 1-11.

APHA (2012). Standard Methods for the Examination of water and wastewater, $22^{\text {nd }}$ Edition. American Public Health Association, American Water Works Association and Water Environment Federation, Washington, DC. USA.

Azeez, R. A. (2010). A Study on the effect of temperature on the treatment of industrial wastewater using Chlorella vulgaris Alga. Eng. Tech. J., 28(4):1-8.

Bechet, Q.; Laviale, M.; Arsapin, N.; Bonnefond, H. and Bernard, O. (2017). Modeling the impact of high temperatures on microalgal viability and photosynthetic activity. Biotechnol Biofuels., 10:136.

Bikram, B.; Biswanath, B. and Apurba, D. (2014). Studies on the potential use of sugarcane bagasse as carrier matrix for immobilization of Candida tropicalis PHB5 for phenol biodegradation. Int. Biodeter. Biodegrad., 93:107-117.

Boominathan, M. (2005). Bioremediation studies on dairy effluent using cyanobacteria, Ph.D. Thesis, Bharathidasan University, Tiruchirapalli, Tamil Nadu, India, pp.1-92.

Borowitzka, M. A. (1998). Limits to growth, in Wastewater treatment with algae, Wong, Y. S. and Tam, N. F. Y. Editors. Springer Verlag. p. 203-226.

Butterwick, C.; Heaney, S. I. and Talling, J. F. (2005). Diversity in the influence of temperature on the growth rates of freshwater algae, and its ecological relevance. Fresh w. Biol., 50(2):291-300.

Campos-Rudin, M. and Silva-Benavides, A. M. (2018). Ammonium and phosphate removal using batch laboratory cultures by microalgae and cyanobacteria isolated from Costa Rica water bodies. Int. J. Trop. Biol., 66(1): S83-S91.

Cassidy, M. B.; Lee, H. and Trevors, J. T. (1996). Environmental applications of immobilized cells: a review. J. Ind. Microbiol., 16:79-101. 
Chaney, A. L. and Marbach, E. P. (1962). Modified reagents for determination of urea and ammonia, Clin.Chem., 8(2): 130-132.

Clark, J. M. and Switzer, R. L. (1977). Experimental Biochemistry. W. H. Freeman, Company San Francisco (Eds.) (2nd edition), P 4.

Cruz, I.; Bashan, Y.; Hernandez-Carmona, G. and De-Bashan L. E. (2013). Biological deterioration of alginate beads containing immobilized microalgae and bacteria during tertiary wastewater treatment. Appl. Microbiol. Biotechnol., 97:9847-9858.

Daliry, S.; Hallajsani, A.; Mohammadi Roshandeh, J.; Nouri, H. and Golzary, A. (2017). Investigation of optimal condition for Chlorella vulgaris microalgae growth. Global J. Environ Sci Manage., 3(2):217-30.

De la Noüe, J. and Proulx, D. (1988). Tertiary treatment of urban wastewater by chitosan-immobilized Phormidium sp. In Algal Biotechnology. (Edited by Stadler, T. et al., Elsevier Applied Science, New York, pp. 159-168.

Dixit, D. and Parmar, N. (2013). Treatment of pharmaceutical waste water by electro-coagulation and natural coagulation process: review. VSRD Int. J. Technol. Non Technol. Res., 4(5):79-88.

Dubey, S. K.;Dubey, J.; Mehra, S.; Tiwari, P. and Bishwas, A. J. (2011). Potential use of cyanobacterial species in bioremediation of industrial effluents. Afr. J. of Biotechnol., 10 (7):1125-1132.

Dubois, M.; Gilles, K. A.; Hamilton, J. K.; Rebers, P. A. and Smith, F. (1956). Colorimetric method for determination of sugars and related substances. Analyt. Chem., 28: 350-356.

EL-Sheekh, M. M. and Mahmoud, YA-G. (2017). Technological approach of bioremediation using microbial tools: bacteria, fungi, and algae. In: Bhakta JN (ed) Handbook of research on inventive bioremediation techniques. IGI Global, USA, pp 134-154.

EL-Sheekh, M. M.; Farghl, A.; Gala, H. R. and Bayoumi, H. S. (2016). Bioremediation of different types of polluted water using microalgae. Rend. Fis. Acc. Lincei., 27(2):401-410. 
Elumalai, S.; Saravanan, G. K.; Ramganesh, S.; Sakhtivel, R. and Prakasam, V. (2013). Phycoremediation of textile dye industrial effluent from tirupur district, Tamil Nadu, India. International Journal of Science Innovations and Discoveries, 3(1): 31-37.

Faafeng, B. A.; van Donk, E. and Källqvist, T. (1994). In situ measurement of algal growth potential in aquatic ecosystems by immobilized algae. $J$. Appl. Phycol., 6: 301-308.

Fedorova, G.; Golovko, O.; Randak, T. and Grabic, R. (2014). Storage effect on the analysis of pharmaceuticals and personal care products in wastewater. Chemosphere, 111:55-60.

Ho, SH.; Chen, CY. and Chang, JS. (2012). Effect of light intensity and nitrogen starvation on $\mathrm{CO}_{2}$ fixation and lipid/carbohydrate production of an indigenous microalga Scenedesmus obliquus CNW-N. Bioresour. Technol., 113: 244-252.

Jimenez-Perez, M. V.; Sanchez-Castillo, P.; Romera, O.; Fernandez-Moreno, D. and Perez- Martinez, C. (2004). Growth and nutrient removal in free and immobilized planktonic green algae isolated from pig manure. Enzyme Microb. Technol., 34: 392-398.

Kshirsagar, C. (2010). Ecofriendly and cost effective treatment of herbal and bulk drug pharmaceutical wastewaters using Spirulina, Indian $J$. Environmental Protection, 30: 773-779.

Kvarnryd, M.; Grabic, R.; Brandt, I. and Berg, C. (2011). Early life progestin exposure causes arrested oocyte development, oviductal agenesis and sterility in adult Xenopus tropicalis frogs. Aquat. Toxicol., 103: 18-24.

Larsdotter, K. (2006). Wastewater treatment with microalgae - a literature review. Vatten, 62:31-38.

Lau, P. S.; Tam, N. F. Y. and Wong, Y. S. (1995). Effect of algal density on nutrient removal from primary settled wastewater. Environ. Pollut., 89: $56-66$.

Lau, P. S.; Tam, N. F. Y. and Wong, Y. S. (1997). Wastewater nutrients (N and P) removal by carrageenan and alginate immobilized Chlorella vulgaris. Environ. Technol., 18: 945-951. 
Lee, J.; Lee, J.; Shukla, SK.; Park, J. and Lee, TK. (2016). Effect of algal inoculation on COD and nitrogen removal and indigenous bacterial dynamics in municipal wastewater. J. Microbiol. Biotechnol., 26:900908.

Lessel, TH. (1994). Upgrading and nitrification by submerged bio-film reactorsexperiences from a large scale plant. Water Sci. Technol., 29:167-174.

Li, H. j.; Wang, J. and Zhang, J. L. (1991). Removal of nutrient salts in relation with algae in ponds. Water Sci. and Tech., 24:5, 75-83.

Lowry, O. H.; Rosebrough, N. J.; Farr, A. L. and Randall, R. J. (1951). Protein measurement with the Folin phenol reagent. J. Biol. Chem., 193: 265-275.

Mahapatra, D. M.; Chanakya, H. N. and Ramachandra, T. V. (2013). Treatment efficacy of algae-based sewage treatment plants, Environ. Monit. and Assess., 185(9):7145-7164.

Malakootian, M.; Hatami, B.; Dowlatshahi, S. and Rajabizadeh, A. (2015). Optimization of culture media for lipid production by Nannochloropsis oculata for Biodiesel production. Environmental Health Engineering and Management Journal, 2(3):141-147.

Mallick, N. (2002). Biotechnological potential of immobilized algae for wastewater N, P and metal removal: a review. Biometals., 15:377-390.

Mandal, S. and Mallick, N. (2009). Microalga Scenedesmus obliquus as a potential source for biodiesel production. Appl. Microbiol. and Biotechnol., 84 (2):281-291.

Moreira, SM.; Moreira-Santos, M.; Guilhermino, L. and Ribeiro, R. (2006). Immobilization of the marine microalga Phaeodactylum tricornutum in alginate for in situ experiments: bead stability and suitability. Enzyme Microb. Technol., 38:135-141.

Ozkurt, I. (2009). Qualifying of safflower and algae for energy. Energy Educ. Sci. Tech., 23:145-51. 
Promya, J.; Traichaiyaporn, S. and Deming, R. (2008). Phytoremediation of kitchen wastewater by Spirulina platensis (Nordstedt) Geiteler: pigment content, production variable cost and nutritional value. Maejo International Journal of Science and Technology, 2(1): 159-171.

Quek, E.; Ting, Y. P. and Tan, H. M. (2006). Rhodococcus sp. F92 immobilized on polyurethane foam shows ability to degrade various petroleum products. Bioresour. Technol., 97:32-38.

Rai, LC. and Mallick, N. (1992). Removal and assessment of toxicity of $\mathrm{Cu}$ and $\mathrm{Fe}$ to Anabaena doliolum and Chlorella vulgaris using free and immobilized cells. W. J. Microbiol. Biotechnol., 8: 110-4.

Ramola, B. and Singh, A. (2013). Heavy metal concentrations in pharmaceutical effluents of Industrial Area of Dehradun (Uttarakhand), India. Int. J. Environ. Sci. Res., 2(2):140-145.

Rana, R. S.; Singh, P.; Kandari, V.; Singh, R.; Dobhal, R. and Gupta, S. (2014). A review on characterization and bioremediation of pharmaceutical industries' wastewater: an Indian perspective. Appl. Water Sci.,7:1-12.

Rao, P.; Kumar, R. R.; Raghavan, B. and Sivasubramanian, V. (2011). Application of phycoremediation technology in the treatment of wastewater from a leather-processing chemical manufacturing facility. Water SA. 37(1): 7-14.

Revathi, S.; Kumar, S. M.; Santhanam, P.; Kumar, S. D.; Son, D. and Kim, M-K. (2017). Bioremoval of the indigo blue dye by immobilized microalga Chlorella vulgaris (PSBDU06). J. Sci. Ind. Res., 76(1):50-56.

Ricart, M.; Guasch, H.; Alberch, M.; Barcelo, D.; Bonnineau, C.; Geiszinger, A.; Farre, M.; Ferrer, J.; Ricciardi, F.; Romani, A. M.; Morin, S.; Proia, L.; Sala, L.; Sureda, D. and Sabater, S. (2010). Triclosan persistence through wastewater treatment plants and its potential toxic effects on river biofilms. Aquat. Toxicol., 100(4):346-353.

Rippka, R.; Deruelles, J.; Waterbery, J. B.; Herdman, M. and Stainer, R. Y. (1979). Generic assignments, strain histories and properties, pure cultures of cyanobacteria, J. Gen. Microbiol., 111: 1-61. 
Robinson, P. K.; Mak, A. L. and Trevan, M. D. (1986). Immobilized algae: a review. Process Biochem., 21:122-126.

Ruiz-Marin, A.; Mendoza-Espinosa, L. G. and Stephenson, T. (2010). Growth and nutrient removal in free and immobilized green algae in batch and semi-continuous cultures treating real wastewater. Bioresour. Technol., 101:58-64.

Salama, A. M. and Shabana, E. F. (1989). The effects of nitrogen starvation, limitation, and recovery on the growth criteria and nitrogen metabolism of the cyanobacterium Phormidium fragile, Annals of Agric. Sc. Moshtohor, 27:559-571.

Sartory, D. P. and Grobbelaar, J. U. (1984). Extraction of chlorophyll a from freshwater phytoplankton for spectrophotometric analysis. Hydrobiologia, 114:177-187.

Shabana, E. F. (1994). Sewage treatment with microalgae. Sci. J. Fac. Sci. Menoufia Univ., 8: 29-45.

Singh, S. K.; Bansal, A.; Jha, M. K. and Dey, A. (2012). An integrated approach to remove $\mathrm{Cr}$ (VI) using immobilised Chlorella minutissima grown in nutrient rich sewage wastewater. Journal of Bioresource Technology, 104: 257-265.

Tam, N. F. Y. and Wong, Y. S. (1989). Wastewater nutrient removal by Chlorella pyrenoidosa and Scenedesmus sp. Environ. Pollut., 58:19-34.

Tam, N. F. Y. and Wong, Y. S. (1995). Wastewater treatment with microorganisms. The Bull. Fish. Res. Bd. Canada, 167-311.

Tam, N. F. Y. and Wong, Y. S. (2000). Effect of immobilized microalgal bead concentrations on wastewater nutrient removal. Environ. Pollut., 107:145-151.

UNESCO (2005). Water resources systems planning and management.

Vanerkar, A. P.; Satyanarayan, S. and Dharmadhikari, D. M. (2013). Full scale treatment of herbal pharmaceutical industry wastewater. Int. J. Chem. Phys. Sci., 2:52-62.

Vijayakumar, S. (2012). Potential Applications of Cyanobacteria in Industrial Effluents-A Review. J. Bioremed Biodeg., 3(154):1-4. 
Vijayakumar, S. and Manoharan, C. (2012). Treatment of dye industry effluent using free and immobilized cyanobacteria. Bioremed. Biodeg., 3(165):16.

Voltolina, D.; Gomez-Villa, H. and Correa, G. (2005). Nitrogen removal and recycling by Scenedesmus obliquus in semicontinuous cultures using artificial wastewater and a simulated light and temperature cycle. Bioresource Technology, 96:359-362.

Vuppala, N. V. S.; Suneetha, C. and Saritha, V. (2012). Study on treatment process of effluent in bulk drug industry. Int. J. Res. Pharm Biomed. Sci., 3(3):1095-1102.

Wang, Y.; Tian, Y.; Han, B.; Zhao, HB.; Bi, JN. and Cai, BL. (2007) Biodegradation of phenol by free and immobilized Acinetobacter sp. strain PD12. J. Environ. Sci., 19:222-225.

Zhou, W. (2014). Potential Applications of Microalgae in Wastewater Treatments. In: Recent advances in microalgal biotechnology. OMICS Group ebook, Foster city, pp 1-9. 


\title{
معالجة مياه الصرف الصيدلانية بإستخدام طحالب السيانوبكتيريا الحرة والمقيدة
}

\author{
عفت فهمي شبانة ، هدى حامد سنوسي ، إنجي بدرالدين خورشيد
}

قسم النبات و الميكروبولوجي، كلية العلوم، جامعة القاهرة، مصر

تعتبر الطحالب من أهم عو امل المعالجة البيولوجية و التي يتم إستخدامها في معالجة مياه الصرف.

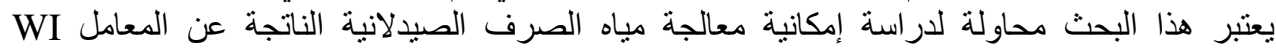

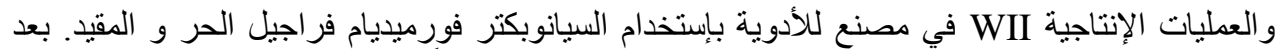

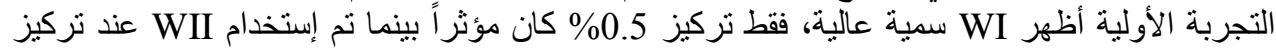

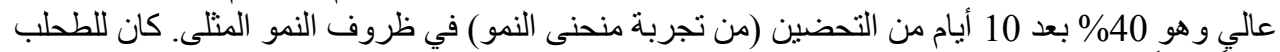

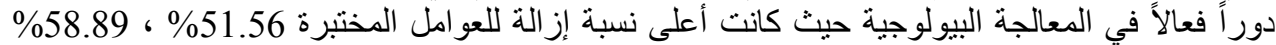

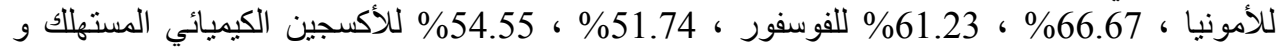

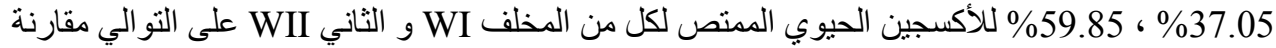

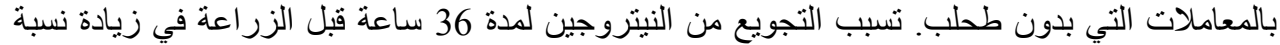

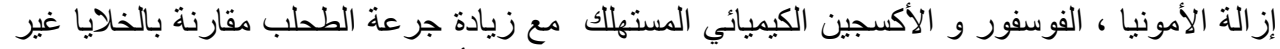

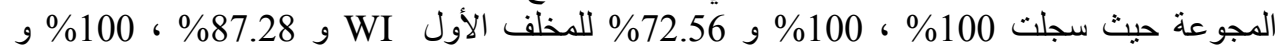

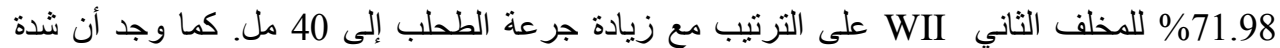

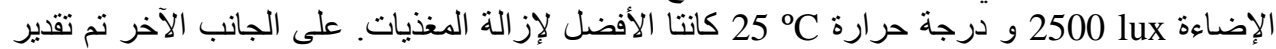

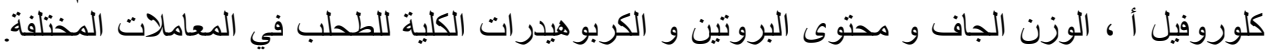

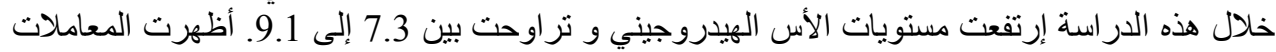

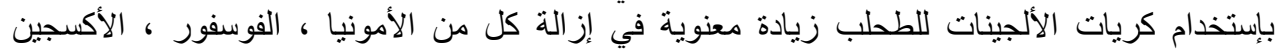

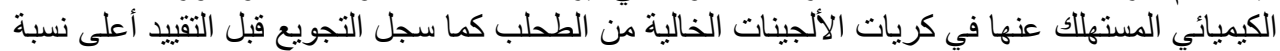

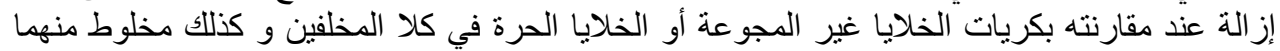

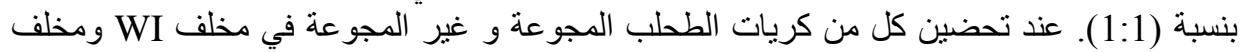

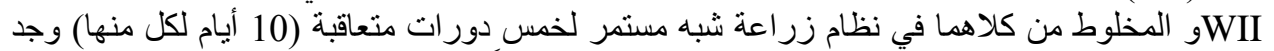

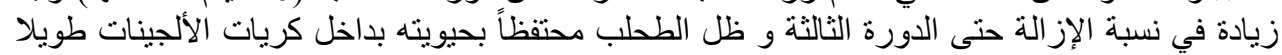

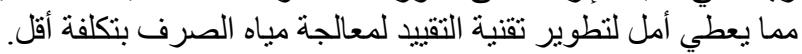

